\title{
SYMBOL I SIGNUM. PRZYCZYNEK DO KRYTYKI TEORII SYMBOLU RELIGIJNEGO
}

Paweł Grad

Uniwersytet Warszawski

Twórczym sposobem spojrzenia na wszelkie pojawienie się trybu symbolicznego jest zadanie sobie pytania: przez jaka teologie zostat on uprawomocniony? Podejście semiotyczne powinno być w stanie rozpoznać również przypadki, w których jego pytanie krytycznie ustanawia, zawierając $z$ nimi rodzaj traktatu, własne bóstwa.

(Eco 1999: 204)

\section{/// 1. Symbol jako pojęcie kompensacyjne}

Pojęcie symbolu jest jednym z podstawowych narzędzi, za pomoca których nowoczesna umysłowość próbuje oswoić zgorszenie, jakie stanowi dla niej religia i jej przednowoczesne dziedzictwo. Miejsce pojęcia symbolu religijnego w naukach społecznych mówi więcej o nowoczesnej pozycji religii i procesie sekularyzacji niż o samej strukturze języka religijnego.

Stworzone na nowo u progu nowoczesności w niemieckim romantyzmie pojęcie symbolu miało stać się kluczem otwierającym drzwi do światów, na które zamknęła się nowoczesność - do wszystkiego, co pochodząc z innej epoki, nie mieściło się w normach, które sekularny rozum wyznaczył temu, co racjonalne. „Jako konieczna konkluzja wynika z całego postępowania badawczego, co następuje: mitologię w ogóle, a zwłaszcza wszelką poezję mitologiczną trzeba pojmować nie schematycznie ani alegorycznie, a tylko symbolicznie" (Schelling 1983: 78). Zanim jednak ta konkluzja dotycząca mitologii, będącej dla romantyków metonimią religii w ogóle, mogła paść z ust autora Filozofii objawienia, potrzeba było subtelnego procesu zmian znaczenia pojęcia symbolu, którego najbardziej znanymi bohaterami są Goethe i Schiller, a który zaczął się - jak wiele nowoczesnych zjawisk w świecie idei - od Kanta. W Krytyce władzy sqdzenia ustosunkowuje się on expressis verbis do dotychczasowego użycia tego pojęcia: „Jest to wprawdzie przyjęty przez nowszych logików, ale wypaczający sens, niewłaściwy uży- 
tek słowa «symboliczny», gdy przeciwstawia się je intuitywnemu sposobowi przedstawienia; symboliczny bowiem jest tylko odmianą intuitywnego" (Kant 2004: 299). Kant próbuje tu wyrwać pojęcie symbolu logikom i oderwać je od pierwotnego, utrwalonego znaczenia, zgodnie z którym symbol to tyle co znak konwencjonalny. Schiller i Goethe oraz jego przyjaciel Heinrich Meyer, autor pierwszego publicznego przeciwstawienia symbolu i alegorii (por. Todorov 2011: 225-229), jako uważni czytelnicy Kanta zrobią z tej wskazówki użytek, który wraz z koncepcjami Schlegla złoży się na romantyczny przełom w rozumieniu pojęcia symbolu. Symbol staje się za jego sprawą centralnym pojęciem romantycznej estetyki. Oznacza on znak, który pozwala w poza- lub ponadracjonalny, intuitywny i nieabstrakcyjny sposób uczestniczyć w niewysłowionej pełni (por. tamże: 177-211). Spełnia on rolę artystycznego „sakramentu”, który otwiera drogę do zjednoczenia z absolutem poza możliwością intelektualnej penetracji (por. Eco 1999: 167, Schelling 1983: 120). Symbol nie jest tylko narzędziem semiotycznym, przyporządkowanym konwencjonalnie desygnatowi jak alegoria: pełni on swoją funkcję, pozwalając uczestniczyć w tym, co oznacza, i dlatego nie można go odrzucić po uchwyceniu tego, do czego odsyła. Dlatego Schelling może powiedzieć, że „wymogiem mitologii zaś jest właśnie n ie to, aby jej symbole tylko oznaczały idee, ale aby zachowując znaczenie ze względu na same siebie były istotami niezależnymi” (Schelling 1983: 120). Mitologia nie opiera się więc na alegoriach (w których element znaczący ulega zniesieniu, gdy spełni swe zadanie), ale na symbolach, które intuitywnie i afektywnie udostępniają to, co znacza.

Pamiętając, że zapośredniczenie rozumu i religii w sztuce było dla niemieckiego romantycznego idealizmu droga uzdrowienia pozbawionej uczucia i wiary nowoczesności (por. Hegel 1999: 275-277, Habermas 2007: 58-64), można uznać, że dokonana tu reinterpretacja pojęcia symbolu zaprojektowana jest bardzo precyzyjnie i uderza w sedno przednowoczesnej semiotyki teologicznej. Ta ostatnia uległa zniesieniu w historii (wyczerpanie Objawienia) i powinna zostać teraz świadomie przekroczona. Paradygmatem znaku w ortodoksyjnej teologii była alegoria - pochodzący z ustanowienia Boga znak przyporządkowujący rzeczywistość widzialną i ziemską niewidzialnej i boskiej w sposób, który umożliwiał jego intelektualną penetrację za pomocą rozumu przenikniętego wiarą (Lubac 2000: 113-117). Chodzi tutaj zawsze o konwencjonalny znak, który przyporządkowany jest zewnętrznej wobec niego i niemoźliwej do zamknięcia w nim rzeczywistości. Zakwestionowanie tego schematu wyznacza moment, w którym na poziomie teoretycznym uznano nieaktualność teologicznej teorii znaku 
i postanowiono opracować ją na nowo, w sposób dostosowany do założeń epoki i odpowiadający poczuciu zaciemnienia się Objawienia. Świadomie lub nie, kanoniczne próby sformułowania poromantycznej teorii symbolu religijnego podane przez Paula Tillicha (por. Tillich 1966, Tillich 1996) i Paula Ricœura (por. Ricœur 2008: 477-500) są uzależnione od romantycznego przekształcenia tego pojęcia i tym samym zachowują stojące za nim założenie o samozniesieniu się Objawienia chrześcijańskiego. Warto zauważyć, że obaj ci autorzy związani są z protestancką tradycją teologiczną, która najsilniej naznaczyła również niemiecki idealizm. Symbol z wielkich historiozoficznych projektów XIX wieku, których ambicją było pojednanie nowoczesności z porzuconą przez nią religijna przeszłością, trafił do skromniejszych i bardziej naukowych prób interpretacji ,,języka religii” (por. Jung 1934, Eliade 1998, Ricœur 1985a, 1985b, 1985c, Lurker 1994). Tu pozwolić miał nowoczesnej nauce obcować w bezpieczny a zarazem pełen zrozumienia sposób z ,nienowoczesnym” i „nienaukowym” fenomenem religii.

Cała wywodząca się z niemieckiej estetyki romantycznej tradycja pojęcia symbolu utwierdza nas w przekonaniu, że jego struktura i użycie pozwalają lepiej wyjaśnić specyficznie nowoczesna próbę zrozumienia symbolicznie niemocnego języka religijnego niż źródłowo religijne, „symboliczne” rozumienie rzeczywistości. To, czego używamy zarówno w nowoczesnym dyskursie religijnym, jak i w naukach społecznych jako pojęcia „symbolu religijnego", jest pojęciem kompensacyjnym, które pozwala zaabsorbować koszty procesu alienacji treści religijnych i zaciemnienia Objawienia, jednocześnie zachowując nowoczesne struktury pojęciowe. Tezę tę uzasadnię, podając szkic alternatywnej semiotyki języka religijnego. Będę starał się dowieść, że język religijny charakteryzuje się: (1) semantycznym zdefiniowaniem znaczenia znaków, (2) syntaktyczną koherencją wewnętrzną i (3) pragmatycznym sprzężeniem z określoną dyscypliną. Cechy te odróżniaja go od romantycznego języka symboli, które z zasady mają niedodefiniowane znaczenie, wchodzą miedzy sobą w luźne związki rządzone prawem poetyckiego przetworzenia i obliczone są na spontaniczne, wolne od przymusu przyswojenie. We wszystkich tych trzech aspektach semiotycznych cechą konstytutywną języka religijnego jest wzmacnianie różnicy między systemem religijnym a profanicznym środowiskiem. Nowoczesna destabilizacja systemów religijnych wymusiła adaptację przez redukcję niemożliwych do utrzymania różnic (między Bogiem i naturą, herezją i ortodoksją, dyscypliną i wolnościa). Możemy zatem potraktować problem symbolu jako przyczynek do zrozumienia nowoczesnych losów języka religijnego. 
W tym celu podejmę się tutaj wyartykułowania przednowoczesnej semiotyki teologicznej i skonfrontowania jej z postromantyczną teorią symbolu.

Gdy próbujemy napisać historię pojęcia symbolu, cofając się przed epokę nowoczesną, natrafiamy na fundamentalną trudność: pojęcie to nie ma tam nigdy znaczenia podobnego do romantycznego. W tradycji logiki sięgającej Arystotelesa symbol oznaczał po prostu znak konwencjonalny (w odróżnieniu od znaków naturalnych, które dziś określilibyśmy raczej jako symptomy). W tym znaczeniu pojęcie symbolu jest zresztą używane również dziś w standardowych teoriach semiotycznych i ma ono niewiele wspólnego ze specyficznie nowoczesnym rozumieniem symbolu, o czym zapewnił nas już Kant (2004: 299). W innym znaczeniu, związanym z tradycją egzegetyczną, symbol jest pojęciem zbliżonym do metafory oraz alegorii i odnosi się do duchowego sensu Pisma Świętego przeciwstawionego sensowi literalnemu (por. Tomasz z Akwinu 1929: 18). Brak tu jednak precyzyjnego odróżnienia, a zwłaszcza przeciwstawienia symbolu alegorii, które jest konstytutywne dla jego nowoczesnego rozumienia. Wśród przednowoczesnych koncepcji znajdujemy wreszcie symbol w znaczeniu ściśle teologicznym, co samo w sobie mogłoby być dla nas najbardziej obiecujące, jednak pełni on tam funkcję zupełnie odmienną od romantycznej: występuje - i to najczęściej przynajmniej w łacińskim średniowieczu (Ladner 1978: 225) - po prostu w znaczeniu symbolu apostolskiego (credo), czyli wyznania prawd wiary wypowiadanego podczas liturgii. Złożenie wyznania w ustalonej formie symbolu pozwala poświadczyć przynależność składającej go osoby do wspólnoty Kościoła. Symbol ma więc tutaj sens związany $\mathrm{z}$ etymologicznym znaczeniem słowa symbolon - fizycznego znaku w postaci fragmentu przełamanego przedmiotu, który po złączeniu ze swoją brakującą częścią pozwala rozpoznać się członkom tej samej wspólnoty.

Ostatnie użycie pojęcia symbolu, podobnie jak dwa poprzednie, jest dalece niewystarczające, by zrekonstruować teologiczny model semiotyczny dający się funkcjonalnie zestawić z modelem nowoczesnym. By to zrobić, musimy zwrócić się ku ogólniejszej teorii semiotycznej rozwiniętej na gruncie teologii, która konceptualizuje problem języka religijnego za pomocą odmiennych, ale ekwiwalentnych pojęć (por. Ladner 1979: 227). Teorię taką postaramy się wyartykułować, korzystając z fundamentalnych intuicji semiotycznych zawartych implicite w tekstach św. Augustyna. Powinniśmy więc pamiętać o ograniczoności uzyskanej w ten sposób perspektywy, która odnosić się będzie w pierwszym rzędzie do teologii chrześcijańskiej. Ograniczenie te posiada jednak pewne uzasadnienie w fakcie, że to właśnie na gruncie chrześcijaństwa rozwinęły się nowoczesne procesy transformacji 
i sekularyzacji treści religijnej, których częścią jest postromantyczna teoria symbolu. Postępować będziemy, przyjmując za punkt odniesienia elementy klasycznego schematu semiotycznego wywodzącego się od Morrisa (por. Morris 1944): po (2) przeanalizowaniu wynikającej z koncepcji Augustyna teorii znaku religijnego (semantyki) przejdziemy do (3) teorii struktury języka religijnego (syntaktyki), by wreszcie naświetlić (4) kontekst towarzyszących mu praktyk (pragmatykę).

\section{/// 2. Semantyka: rzeczy i znaki}

Omnis doctrina vel rerum est vel signorum, sed res per signa discuntur, „Cała nauka odnosi się do rzeczy albo do znaków, z tym że rzeczy poznajemy przez znaki” (Augustyn 1989: 10-11). Jest to fundament augustiańskiej semantyki; zaanonsowane zostaja w nim we wzajemnym powiązaniu pierwsze dwie z kluczowych opozycji strukturyzujących siatkę pojęciową Augustyna: doctrina-disciplina (jako discuntur) oraz res-signa. Doctrina odnosi się do słów i rzeczy, lecz rzeczy poznajemy (discuntur) przez znaki. Poznawanie (discere) - być może tylko poza poznaniem przedmiotów zmysłowych, które nie wymaga pośrednictwa znaków (Jackson 1969: 11) - utożsamia się z posługiwaniem się znakami: znaki służą temu, by poznawać; ich funkcja spełnia się w odsłanianiu rzeczy. Choć znaki same stanowia „rzeczy, których używa się na oznaczenie czegoś" (Augustyn 1989: 13), to mają one czysto instrumentalny charakter: służą temu, by poznać rzeczy, które ,jako takie istnieją, ale poza sobą na nic innego nie wskazują, czyli nie znaczą" (tamże). Celem znaków jest samozniesienie: u kresu poznania mają odpaść, by pozostawić rzecz samą. Sa one całkowicie przechodnie. Relacja oznaczania zmierza do poznania rzeczy, które nie potrzebuje już znaków.

Teologiczny cel, który przyświeca tu Augustynowi, staje się jaśniejszy, gdy do tych pierwszych odróżnień dodaje on kolejne:

Otóż jednymi rzeczami należy radować się (fruendum est), z innych korzystać (utendum), a wreszcie są i takie, którymi trzeba się nam cieszyć, jak i posługiwać się. Te, którymi należy się radować, czynią nas szczęśliwymi. Te, z których trzeba korzystać, pomagaja nam i niejako wspierają nas w dążeniu do szczęścia, abyśmy mogli zdobyć te, które same czynią nas szczęśliwymi, i do nich przylgnąć. $[\ldots]$ 
Radować się (frui) w rzeczy samej znaczny tyle, co z miłością przylgnąć do jakiegoś przedmiotu miłości ze względu na niego samego. Tymczasem korzystać (uti) to tyle, co przyporządkować przedmiot, którym się posługujemy, do zdobycia obiektu umiłowanego, pod warunkiem, że jest on godny miłości (tamże).

Opozycja uti-frui jest de facto neoplatońską opozycją etyczną, za pomocą której definiuje się właściwy stosunek człowieka do dóbr doczesnych. Ponieważ znaki służą poznaniu rzeczy, klasyfikuja się one całkowicie po stronie uti. Znaków się używa, raduje się zaś (fruere) rzeczami. Radykalna hierarchizacja, jaką wprowadza ta dychotomia, jeszcze mocniej wybija czysto instrumentalny charakter znaków.

„Rzeczy, którymi radować się należy, to Ojciec i Syn i Duch Święty taż sama Trójca jedyna, najwyższa rzecz (summa res), a przy tym wspólna dla wszystkich radujących się nią" (Augustyn 1989: 15). Jedyną rzecza, która naprawdę warto smakować, jest Bóg. W pełni będzie to możliwe w życiu przyszłym, w ojczyźnie. Póki jesteśmy w drodze, zdani jesteśmy na znaki, których powinniśmy używać, by móc smakować tutaj to, czym radować się będziemy poza tym światem. Jest oczywiste, że docieramy tutaj do jednego z podstawowych przekonań średniowiecza: świat jest systemem znaków, czy też księga, która objawia to, co poza nim: „Nie ma takiej rzeczy widzialnej i cielesnej, która by, jak sądzę, nie oznaczała czegoś niewidzialnego i umysłowego” (cyt. za: Eco 2006: 85). Jest to rodzaj „pansemiozy metafizczynej" (tamże: 82-87): cały świat jest tekstem.

Dla teorii semiotycznej ta dość oczywista cecha kultury średniowiecznej ma daleko idące konsekwencje, które dają się precyzyjnie wyartykułować w języku św. Augustyna. Tym, co konstytuuje znak religijny, jest formalna cecha bycia stworzonym - należenia do tego świata, przez który pielgrzymujemy. Jednych rzeczy używamy, innymi się cieszymy - a cieszyć się naprawdę możemy tylko Bogiem. Tylko On może być dla nas wyłącznie rzeczą, skoro bycie nią polega na nieodsyłaniu do niczego innego, czyli byciem przedmiotem czystego fruitio. Oznaczanie jest w teorii Augustyna czysto funkcjonalną kategorią mieszczącą się bez reszty w kategorii uti: „[...] traktując o znakach powiadam, żeby nie zwracać uwagi na ich własne istnienie, lecz raczej na to, że są znakami, czyli że wskazują na coś innego" (Augustyn 1989: 51). Pozwala to potencjalnie uznać każda rzecz - z samego tego faktu, że nie jest ona Bogiem - za znak, który odsyła do jednego, transcendentnego i nieskończonego desygnatu, którym jest Bóg. Znakiem w tej perspektywie może stać się wszystko i wszystko to wskazuje na jedną 
rzecz (Boga), która nie może być już znakiem, nie używa się jej bowiem, lecz nią raduje (por. Simone 1973: 21).

Inaczej niż w symbolu romantycznym, każdy z tych znaków jest przechodni - znika, gdy sięga nieskończonego Boga (co w pełni nastąpić może dopiero w horyzoncie eschatologicznym). Romantyczny absolut rozwija się wewnątrz świata: jako pełnia tworzącej i nigdy niewyczerpanej przyrody oraz jako osiagający swa pełnię w historii Duch. Zadaniem sztuki i filozofii pracujących w symbolu jest sprostanie tej wewnętrznej nieskończoności przez udostępnienie jej w przeżyciu estetycznym. Odpowiednio do tego romantyczny symbol jest sam w sobie nieskończony (ma zawrzeć w sobie pełnię), lecz nie przekracza natury (bo to ona jest absolutem), z którą nas jednoczy - w tym sensie spełnia się w całkowicie zimmanentyzowanym horyzoncie. W znaku św. Augustyna ryzyko poznawcze związane z zetknięciem się z absolutem absorbowane jest przez nieskończoność Boga, a więc po stronie znaczonego - w semiotyce romantycznej symbol sam w sobie, jako znaczący, jest nieskończony. Bez poprawnego uchwycenia tego momentu nie można właściwie zrozumieć specyfiki teologicznej semiotyki, czego natychmiastową konsekwencją sa próby ratowania języka religijnego chrześcijaństwa za pomocą teorii symbolu. Św. Augustyn nie próbuje uratować znaków przez zaabsorbowanie ich problematyczności na poziomie elementu znaczącego - jak w romantycznym symbolu, który daje więcej, niż można wyrazić. W semiotyce teologicznej skończoność treści nieskończonej liczby znaków równoważona jest przez nieskończoność treści jedynej rzeczy, na którą wskazują: Boga. Znaki, zwłaszcza te, które Bóg sam ustanowił, sa jednoznaczne - niemożliwy do wysłowienia jest Ten, do którego one odsyłają. Ostatecznie więc muszą zniknąć, by ustapić widzeniu Boga, lub zostać wzięte w nawias przez uznanie ich „analogiczności” (por. McInerny 1996: 86-101, Shanley 2002: 44-66). Jednak ta ostatnia operacja polega na absorpcji niepewności przez wskazanie na nieskończoność oznaczonego przedmiotu, nie zaś samego znaku. Nieskończony znak, jak w romantyzmie, jest de facto znakiem niedookreślonym, a więc o nieukierunkowanej intencji znaczącej. Znak, by spełniać swoją funkcję, musi być, jak u Augustyna, określony, a niewysławialność Boga - zabezpieczona w inny sposób, za pomocą teorii analogii. Umożliwia to Jego transcendencja, tzn. właśnie wyłączenie z dziedziny znaków. Widzimy tutaj wyraźnie, w jak różny od romantycznego sposób semiotyka teologiczna radzi sobie z podstawowym problemem języka religijnego, jakim jest konieczność mówienia o tym, co niemożliwe do wyrażenia. 


\section{/// 3. Syntaktyka: objawienie}

Doktryna dotyczy systemu znaków kierujących ku Bogu. Spaja je nie tylko ta formalna cecha wspólnego desygnatu (Boga), ale również to, że zostały one przez Niego ustanowione (niektóre w sposób wyróżniony). Język religijny w koncepcji Augustyna w ścisłym sensie konstytuuje to, że został on wypowiedziany przez Boga. System ustanowionych przez Boga znaków składa się na Objawienie, a Bóg to nie tylko jedyny ostateczny desygnat znaków, ale również ich jedyny autor.

„Chociaż o Bogu nic stosownie powiedzieć nie można, mimo to przyjał On posługę głosu ludzkiego i dał nam radować się [naszymi] własnymi słowami wypowiedzianymi na Jego cześć" (Augustyn 1989: 17). Stwierdzenie to zawęża zbiór potencjalnych znaków, obejmujący formalnie całość stworzenia, do tych, które Bóg sam wybrał spośród ludzkich słów, by wskazywały na Niego w sposób szczególny. Te spośród nich, które zyskały Jego szczególny autorytet, stanowią zespół znaków składający się na Objawienie. Wspólne pochodzenie stanowi przesłankę powiązania ich w jeden system. Dlatego przekazana od Boga doktryna może zostać spontanicznie skojarzona przez Augustyna z tym, co stanowi medium Objawienia: z Pismem Świętym.

Jedyność autora Objawienia niesie konsekwencje dla rozważań nad prawdziwością języka religijnego. Spójność powiązań między znakami opiera się na przekonaniu o jedności źródła, z którego pochodzą. Autorytet Boga absorbuje świadomość nieadekwatności języka wobec swojego przedmiotu. Napięcie apofatyczne zostaje zluzowane przez uznanie ustanowienia znaków przez samego Boga, przez co teologiczna teoria semiotyczna może zaakcentować koherencjonalistyczna prawdziwość na poziomie syntaksy (Objawienia).

Politeizm romantyzmu immanentyzuje absolutny punkt odniesienia w obręb stwórczego aktu wytwarzania symboli (por. Todorov 2011: 180_ 185). Koherencja obowiązuje tu autora w obrębie jego własnego systemu i w stosunku do posiadanej ,intuicji”. Natomiast na poziomie intersubiektywnym te „prywatne języki” symbolicznego objawienia nie są skoordynowane w żaden sposób poza miękkim i nieweryfikowalnym kryterium „smaku” (por. Gadamer 2007: 69-79). Nowoczesny ,język sztuki” jest de facto systemem języków, który nie posiada żadnej twardej regulacji poza oceną opinii publicznej. Mechanizmy sterujące selekcją znaków są tu bardziej subtelne i ukryte - inaczej niż w przypadku religijnej ortodoksji, gdzie reguła jest jawna po to, by móc w widzialny sposób wykluczyć nieprawo- 
myślne interpretacje. Nowoczesne mechanizmy selekcji może odsłonić dopiero sięgająca na poziom funkcji ukrytych krytyka systemu. Na poziomie jawnym rządzi w nim reguła wariacji, przetworzenia i cytatu zabezpieczona wolnością wypowiedzi. Sprzyja ona refleksyjnej multiplikacji dyskursów, co ma zresztą zwrotny, sekularyzujący wpływ na odziedziczone w spadku języki religijne (por. Blumenberg 2009: 252-282) - ironiczny dystans wymagany przy artystycznym wytwarzaniu nowych symboli wchodzi w ostre napięcie z wymagającym powagi językiem sacrum (por. Luhmann 1998: 48-49).

Boskie autorstwo w sposób oczywisty wyklucza właściwą romantycznej estetyce ideę wytwarzania symboli religijnych. Objawiony charakter systemu znaków jest podstawowa przesłanką dobrze opisanej tendencji do formułowania nakazów kanonizacji języka religijnego: zachowania go w nienaruszonej formie (por. Assmann 2008: 226-241). Koherencja wynikająca z jedności źródła wymaga zachowania koherencji w czasie, którego upływ oddala od źródeł Objawienia i wystawia system znaków religijnych na wariacje i różnicowanie się. Spójność systemu nabiera charakteru historycznego i zestala się w postaci tradycji.

Reguły syntaktyczne języka Objawienia wynikają z porządku wypowiedzenia znaków, który ustala wewnętrzną strukturę języka. Porządkiem tym jest historia zbawienia. Struktura narracji historycznej implikuje reguły syntaktyczne. Porządek diachroniczny, z pozoru czysto wydarzeniowy i przygodny, z uwagi na to, że jest porządkiem, w którym działa sam Bóg, nabiera charakteru normatywnego i strukturyzuje język Objawienia na poziomie synchronicznym. To dlatego historia jest matryca generatywną gramatyki wiary. Kulminacją historii i jej punktem przełomowym, który stanowi właściwą i jawną wypowiedź Boga - za pomocą doskonale transparentnego znaku - jest wcielenie Chrystusa (por. Augustyn 1989: 21).

Choć sformułowanie „historia zbawienia” jest używane w teologii protestanckiej od drugiej połowy XIX w., a wśród teologów katolickich dopiero od II wojny światowej (por. Lubac 1997: 31), to bez wattpienia przekonanie o „historyczności” zbawienia i objawienia obecne jest w doktrynie chrześcijańskiej od jej początku. Ta sama myśl, przy użyciu sięgających czasów Augustyna pojęć, zawarta jest też jednym z dokumentów Vaticanum II: „[...] ekonomia Objawienia realizuje się przez czyny (gestis) i słowa (verbisque) wewnętrznie ze sobą połączone, tak że czyny dokonane przez Boga w historii zbawienia (bistoria salutis) ujawniają i potwierdzają doktrynę (doctrinam) oraz sprawy (res) wyrażone (significat) w słowach; słowa zaś obwieszczaja czyny i rozświetlają zawartą w nich tajemnicę (mysterium)" (Dei Verbum I, 2). 
Do wypowiedzenia historyczności objawienia służy tu semiotyczna terminologia: res, verbis, doctrina, significare. Krystalizująca się w ten sposób struktura pojęć, której Augustyn jest tylko jednym z autorów, wyraźnie ujmuje Objawienie jako system znaków, które układają się we wzajemnych odniesieniach, tworząc narrację. Język objawienia nie jest prostym agregatem znaków; wypowiedziany przez Boga, jest historyczny, to znaczy ma charakter opowieści. Znaki w nim zawarte łączą się ze sobą w narrację. Wewnętrzna racjonalność systemu znaków nie sprowadza się jedynie do ich koherencji - jest ona logiką opowieści, w której wychodząc od stanu początkowego, zmierza się do pewnego określonego wypełnienia, ku któremu kierują historyczne okoliczności. Dlatego dogmatyka, choć może się stać przedmiotem kontemplacji wznoszącej się ponad to, co historyczne, daje się również zoperacjonalizować jako narracja, którą Bóg opowiada sam o sobie.

Z punktu widzenia historii idei postawienie kwestii prawdziwości języka religijnego w ekskluzywnie referencjalistycznych kategoriach, choć stanowi rozwinięcie pewnej tendencji rozwijającej się w obrębie samej teologii, nie pozwala w pełni zdać sprawy z charakteru systemu języka religijnego, w którym poruszał się np. św. Augustyn. Prawdziwość znaków religijnych w tym systemie weryfikuje się pośrednio przez możliwość odniesienia ich do praktyki i ze względu na ich narracyjną nośność.

W teologicznym systemie semiotycznym paradygmatyczną strukturą syntaktyczną języka Objawienia jest struktura „typu” i „wypełnienia”. W klasyczny sposób wyraża się w niej z jednej strony świadomość „historyczności” Objawienia, a z drugiej - rodzaj przyporządkowania między znakami właściwy semiotyce teologicznej. Typ jest bowiem ustanowionym przez Boga, konwencjonalnym znakiem ze Starego Testamentu, którego sens pozostawał ukryty i niejawny, dopóki nie wyjaśniły go czyny i słowa Jezusa. Choć metoda typologiczna jest genetycznie powiązana $z$ hellenistycznymi i rabinistycznymi metodami interpretacji, to $\mathrm{w}$ tym punkcie wyraża ona specyficznie chrześcijańską koncepcję. Opiera się na Pawłowej dialektyce między „literą” a „Duchem” z Listu do Rzymian. Zgodnie z nią Chrystus wypełnia „skryty pod litera” sens objawienia Starego Testamentu, czyniąc to, co było dawniej tajemnica, czymś jawnym i przejrzystym. Objawienie dane w Chrystusie zrywa zasłonę z tego, co dla Izraela miało sens niejawny - po Chrystusie uzyskany zostaje dostęp do tajemnic, poddaja się one poznawczej penetracji za pomocą wiary (por. Ratzinger 2011: 59-64). Rdzeń tej myśli tkwi w Pawłowej dialektyce prawa: Chrystus, wypełniając prawo (literę), znosi je - zostaje ono zachowane w odsunięciu 
jako tło, na którym przejrzysty staje się duchowy sens tego, co dokonało w Chrystusie. W tym sensie dialektyka ta jest wspólnym źródłem „typu” (odsłonięcia w planie historycznym) i „alegorii” (odsłonięcia w planie wertykalnym, wewnątrz tekstu), które to pojęcia zazwyczaj się rozróżnia. Obie te figury semiotyczne opisuja przejście od znaczenia literalnego do duchowego: na gruncie chrześcijańskiej hermeneutyki ruch ten umożliwia Chrystus. Z tego punktu widzenia „misteryjny” charakter romantycznego symbolu jest regresem do etapu struktur semiotycznych akceptujących nieprzejrzystość znaków - przed etap ostatecznego Objawienia. Diagnoza ta skądinąd dobrze gra z politeistycznymi i pogańskimi sympatiami romantyków.

Interesująco wypada też porównanie związku między koncepcją znaku religijnego i historia zbawienia a romantycznym symbolizmem i nowoczesnym odkryciem historii. Jest czymś znaczącym, że zarówno „symbol”, jak i „dzieje” stanowią dwa wielkie odkrycia niemieckiego romantyzmu, pozostając ze sobą w ambiwalentnym związku. Romantyzm odkrywa nie tylko symboliczny ładunek historii, ale i artystyczną wartość indywidualnej biografii. Z jednej strony romantyczne dzieło artystyczne jest wytworem geniuszu, a genialny artysta stwarza swój „język”, by wrazić siebie. W stosunku do chrześcijańskiej teologii dziejów romantyzm umniejsza rolę kolektywnej historii kosztem biografii, dokąd ucieka się pod presją rozpędzonej historii. Z drugiej strony „dziejowość” staje się centralnym zagadnieniem tej samej nowej hermeneutyki spod znaku Schleiermachera i Diltheya, która zrobiła wielki użytek z pojęcia symbolu. Nie bez powodu zresztą zauważano, że przedstawienie dziejów samo ma charakter „estetyczny” (por. Heidegger 2007: 498-505) i jest częścią tej samej koncepcji, która starała się opisać kontemplację niewypowiadalnego w symbolu. Ostatecznie okazało się jednak, że o ile projekty filozofii dziejów musiały ogłosić upadłość z końcem długiego wieku XIX (por. Löwith 2001: 215-246), o tyle politeistyczna estetyka autonomicznych systemów symbolicznych przetrwała koniec nowoczesności. W czasach końca historii w obrębie biografii wciąż wytwarza się własne języki i systemy symboliczne, które oferuja pewną estetyczna kompensację, mimo że nikt już nie wierzy, iż rzeczywiście wyjaśniają samą rzeczywistość (por. Rorty 2009: 121-153). Zredukowane do pragmatycznego (w sensie filozoficznym) horyzontu, mają służyć jedynie tłumaczeniu praktyki społecznej i nie mają ambicji totalnego wyjaśnienia historii, która przecież się skończyła. Do tego potrzeba by kogoś, kto stanąłby ponad nią, tzn. Boga - a posthistoryczna ponowoczesność nie zna nikogo takiego. 


\section{/// 4. Pragmatyka: doktryna i dyscyplina}

Dialog O nauczycielu rozpoczyna się następującym pytaniem Augustyna: „Jak sądzisz, w jakim celu posługujemy się mową?”. Odpowiada na nie Adeodatus, jego syn: ,[...] chcemy albo uczyć (docere), albo być pouczanymi (discere)" (Augustyn 1961: 3, por. Augustyn 1999: 433). Docere-discere to kolejna konstytutywna para pojęć semiotyki teologicznej. Słów, a więc szczególnego rodzaju znaków, używa się po to, by przekazywać lub przyjmować pouczenie. Pierwsza część dialogu, w której ojciec i syn w zawiły sposób rozważają konieczność użycia znaków, ich rodzaje i wzajemne relacje, trwa aż do momentu, gdy swobodna wymiana myśli przerwana zostaje przez zasadniczą wątpliwość Augustyna. Daje się ona streścić następująco: skoro, jak ustalono w trakcie dialogu, niczego nie możemy poznać (tzn. być o tym pouczonymi, discere) bez pośrednictwa znaków, a znajomości słów nabieramy dopiero z czasem, to system języka jest od zewnątrz zamknięty: nikt nie może nas wprowadzić w niego przy użyciu samych tylko słów (por. Augustyn 1999: 469-475). Jednocześnie wydaje się, że inaczej w ogóle nie da się nikogo w niego wprowadzić. W tym momencie Augustyn ex cathedra udziela odpowiedzi na ten teoretyczny impas: wiedzy nie zdobywamy za pomoca mowy - uzyskujemy ja wcześniej i inną drogą. Słowa w rzeczywistości mają charakter mnemotechniczny: są znakami, dzięki którym stawiamy sobie przed oczy to, co już wcześniej pojęliśmy swoim umysłem. Tylko bowiem mając wcześniejszą wiedzę, możemy rozumieć słowa. Mowa jest jedynie przepływem obrazów, a udzielane nam za pomocą słów pouczenie - gromadzeniem wiedzy za pomocą techniki przypominania.

Jak jednak możliwe jest poznanie istoty rzeczy poprzedzające język i kto może go udzielić? Oto odpowiedź Augustyna:

[słuchacz] uczy się [...] nie z mych słów, lecz dzięki temu, że Bóg przed oczami jego duszy odsłania same rzeczy. [...] [P]rawdziwe są słowa Ewangelii zapisane z natchnienia Bożego, że nie należy nikogo na ziemi nazywać nauczycielem, ponieważ jeden jest tylko Nauczyciel w niebie. [...] Za jego sprawą zewnętrzne znaki ludzkie przypominają nam, abyśmy wewnątrz duszy zwróceni ku Niemu poznali prawdę; ukochać Go i poznać - to znaczy osiagnnąć szczęśliwe życie (Augustyn 1999: 479).

Fragment ten ma daleko idące konsekwencje dla pragmatyki języka religijnego. Ustanowione przez Boga znaki, powiązane ze sobą w narra- 
cji Objawienia, mogą być zrozumiane dzięki aktowi, jakim jest nawrócenie (scil. dzięki odsłonięciu ich sensu w przeddyskursywnym „wnętrzu”). Pragmatyka ta zakłada zatem określoną koncepcję antropologiczną i etyczną, w myśl której ludzkie działanie ma radykalnie teleologiczny charakter i może się realizować przez określone dyspozycje (cnoty) (por. Spaemann, Löw 2008: 3-18). Transcendencji desygnatu na poziomie znaków odpowiada zewnętrzność celu, do którego ludzkie działanie zmierza według tychże znaków. Dlatego doctrina christiana nie jest po prostu teorią hermeneutyczną (por. Press 1984), lecz pouczeniem, które funkcjonalnie (jako doktryna) definiuje się w kategoriach etyki celów i towarzyszącej jej koncepcji wychowania. Gdzie jest doktryna, musi być nauczyciel - gdzie jest nauczyciel, tam musi być model wychowania. Nie może się ono odbyć bez koncepcji ludzkiej natury, która realizuje się przez osiąganie leżących poza jej aktualnym stanem celów - tylko tak możliwe jest wychowanie jako pewien proces. Wniosku tego nie zmienia nawet fakt, że analizowany tu fragment z De Magistro zawiera wczesna, radykalną wersję teorii idei wrodzonych, która została przez św. Augustyna przekroczona wraz z rozwojem jego własnej teorii iluminacji (por. Gilson 1953: 95-100). Zasadnicza struktura myśli pozostaje ta sama: w system znaków odsłaniających rzeczywistość duchową (znaków religijnych) musi wprowadzić Nauczyciel, otwierając go „od wewnątrz" przed człowiekiem.

O ile doktryna stanowi naukę przekazaną temu, kogo się poucza (docere), a zatem ujęta jest od strony nauczyciela, o tyle dyscyplina jest sposobem jej przyswojenia przez uczenie się (discere), a więc nauką ujętą od strony ucznia. Wprost mowa jest o tym w innym, mniej znanym piśmie Augustyna Sermo de disciplina christiana:

[...] domem dyscypliny jest Kościół Chrystusowy. Czego jednak się tutaj uczy i w jakim celu? Kto się uczy i przez kogo jest nauczany? Uczy się dobrego życia (bene vivere). Uczy się dobrego, by osiągnąć wieczne. Uczą się (discunt) chrześcijanie, naucza (docet) Chrystus (Augustyn 1969: 207).

Doktryna (nauka o celu ostatecznym) zakłada dyscyplinę (technikę działania). Związek ten, oczywisty przy założeniu opisanej wyżej koncepcji etycznej, zasygnalizowany jest tutaj za pomocą retorycznej frazy (discuntdocet) na poziomie etymologicznym. Pragmatyka systemu języka religijnego kontynuuje w tym punkcie tę samą tendencję, która przejawiała się na poziomie semantycznym i syntaktycznym. Znaki odnoszą się do transcen- 
dentnego Boga. Zawarte są w Objawieniu, które pochodzi od Niego. Powinny być przyjęte zgodnie z tym, do czego się odnoszą i skąd pochodzą: w strukturze radykalnej asymetrii między tym, kto ich udziela, a tym, kto je przyjmuje. Jest to wertykalna relacja między nauczycielem a uczniem. Dyscyplinarna struktura Kościoła służąca przekazywaniu doktryny oparta jest na instytucjonalnej reprezentacji boskiego autorytetu nauczycielskiego.

Przekształcenie koncepcji natury we wczesnej nowożytności i zniesienie klasycznie rozumianej teleologii u progu romantyzmu - widoczne zwłaszcza w dziele Rousseau (Spaemann, Löw 2008: 157-218) - pociagnęły za sobą również zmianę w koncepcji wychowania i umożliwiły postawienie kwestii opresyjności struktur symbolicznych jako problemu kultury. Posługujące się nieuchronnie przymusem i dyscypliną wychowanie może być odebrane jako nieodpowiednie tylko tam, gdzie zanegowano zewnętrzną celowość natury lub cel wpisano w nią samą (zimmanentyzowano). Przy takim przedefiniowaniu teleologii celem ludzkiej natury staje się samorealizacja, tzn. swobodne rozwijanie doskonałości, która już jest w niej zawarta - nie zaś leży poza nią i musi być zdobyta. W tym kontekście jest czymś frapującym, że to samo społeczeństwo, w którym wypracowano tę nową koncepcję wychowania, uległo samoprzekształceniu w społeczeństwo dyscyplinarne.

Szczególna rola, jaka przypada nowej symbolicznej sztuce w projektach romantyków, wynika właśnie z wypracowanej wtedy nowej koncepcji wychowania. Dyscyplina stała się u progu nowoczesności właściwą metoda kształtowania obywateli w sferze publicznej - opisy bujnego rozwoju społeczeństwa dyscyplinarnego po połowę XX wieku stanowią źródło większości skojarzeń, jakie wiąże się współcześnie w naukach społecznych ze słowem „dyscyplina”. Zgodnie zaś z programem romantycznym sztuka odgrywała fundamentalną rolę w sferze prywatnej: pracująca w symbolu sztuka miała stanowić sposób na kompensowanie kosztów nowoczesnego życia przez wolne od przymusu kształcenie duszy. Rolę tę powinna była odgrywać, rozwijając wewnętrzne skłonności natury ludzkiej, nie zaś formując ją zgodnie z zewnętrznym celem - ten ostatni sposób „kształcenia” zarezerwowany był dla politycznego przymusu, który ostatecznie prowadził do alienacji. Tak pomyślana sztuka miała łagodzić skutki zdiagnozowanego przez Rousseau pęknięcia przenikającego nowoczesną tożsamość: pęknięcia między człowiekiem naturalnym a obywatelem (por. Habermas 2007: 58-64). Projekt ten swoje pierwsze sformułowanie znalazł w Listach o estetycznym wychowaniu człowieka Schillera i w zmienionej postaci przetrwał aż po krytykę sztuki rozwijaną przez szkołę frankfurcka. 
Para pojęć doctrina-disciplina strukturyzująca warstwę pragmatyczna języka teologii okazuje się także kluczowa w zrozumieniu metodologicznego problemu, jaki ta dziedzina wiedzy stanowi z punktu widzenia nowoczesnego modelu nauki. Jeżeli uznać, że paradygmatycznym ucieleśnieniem „teologii jako nauki” jest dojrzała scholastyka Tomasza z Akwinu, to warto zauważyć, że autor Summy teologii bardzo rzadko posługuje się pojęciem „teologia”, uprawianą zaś przez siebie naukę nazywa sacra doctrina. Mógłby uczynić inaczej, bo od czasów Piotra Abelarda „teologia” pojawia się jako określenie dyscypliny naukowej. Tomaszowy projekt sacra doctrina wpisuje się w linię biegnącą od doctrina christiana św. Augustyna (por. Congar 1960: 183). Linia ta jest ciagła pomimo zafalowań wywołanych recepcją arystotelizmu w obrębie naznaczonej patrystycznym neoplatonizmem tradycji wczesnej scholastyki. Podstawowe dzieło formacyjne średniowiecznych mistrzów, które komentował również św. Tomasz, czyli Sentencje Piotra Lombarda, oparte zostało na augustiańskich kategoriach res-signa, uti-frui (por. Piotr Lombard 1971: 55-61), a sformułowana w nim koncepcja nauki (doctrina) wprost nawiązuje do De doctrina christiana św. Augustyna. Tomasz, w Summie teologii wybierając pojęcie sacra doctrina (Tomasz z Akwinu 1948: 1) na nazwę wyłożonej w niej dziedziny wiedzy, musiał zdecydować się na nie świadomie, ponieważ nie było ono już tak oczywiste w jego czasach (por. Torrell 2005: 81). Postapił konsekwentnie, bo pomimo jawnego wprowadzenia arystotelesowskiego modelu nauki w pierwszej, metodologicznej kwestii Summy (por. Tomasz z Akwinu 1948: 3) zachowuje on założenia De doctrina christiana na poziomie pragmatyki języka teologicznego. Summa teologii, czyli dzieło traktujące o religii chrześcijańskiej w sposób dostosowany do wykształcenia początkujących (por. tamże: 1), zawiera naukę (doctrina) konieczną do zbawienia, która jest wiedza (scientia) oparta na Objawieniu (por. tamże: 1-2); jest zarówno spekulatywna, jak i praktyczna (por. tamże: 4), i jest mądrością (sapientia) (por. tamże: 5-6). Nie można jej więc oderwać od całościowego systemu religijnego zakładającego określoną teleologię i realizującego się przez wychowywanie jednostek w oparciu o tę naukę. W tym sensie „teologii” nie można oddzielić również od przepowiadania Objawienia i konkretnej praktyki religijnej (dyscypliny).

\section{$* * *$}

Romantyczna redefinicja pojęcia symbolu, stanowiąca próbę konceptualnego zagospodarowania masy upadłościowej przednowoczesnych systemów religijnych, polega na absorpcji przygodnych i niepożądanych różnic 
przednowoczesnego języka religii. Ta nowoczesna funkcja symbolu tłumaczy operacyjną moc tego pojęcia, które z powodów systemowych okazało się niezbędne dla nowoczesnego dyskursu religijnego. Dyskurs ten, a wraz z nim naukowe teorie języka religii, tam gdzie posługuje się pojęciem symbolu, bazuje na jego romantycznym rozumieniu. Rozumienie to pozwala zachować obecność w dyskursie (również naukowym) odziedziczonych treści religijnych pod postacią ,symboli”, jednocześnie znosząc niepożądane różnice strukturyzujące przednowoczesny język religijny: różnicę między właściwym i niewłaściwym znaczeniem znaku religijnego, między elementami spójnymi i niespójnymi z całością Objawienia oraz między posłuszeństwem i nieposłuszeństwem religijnej dyscyplinie. Różnice te, jak widzieliśmy, konstytuują odpowiednio semantyczną określoność znaku, syntaktyczną koherencję i pragmatyczny kontekst użycia języka religijnego. Przednowoczesna semiotyka teologiczna - być może jak każdy system zajęty realizacją właściwej mu funkcji, nie zaś rozpaczliwą walką o adaptację do niesprzyjającego mu środowiska - samodzielnie generowała różnice właściwe strukturze języka religijnego, nie zaś znosiła je w celu przetrwania w usamodzielnionym saeculum. Moment, w którym system rezygnuje z konstytuujących go różnic na rzecz nominalnego przetrwania wobec ekspansji zewnętrznych systemów, należy uznać za początek jego końca jako samodzielnego systemu. Proces ten w odniesieniu do systemów religijnych nazywa się sekularyzacja, na poziomie struktury języka religijnego zaś przebiega jako zamiana znaków religijnych na symbole religijne.

Proces neutralizowania trudnych do utrzymania różnic jest całkowicie zrozumiały w kategoriach funkcjonalnej adaptacji systemu religijnego do zmieniającego się środowiska. Jednocześnie każe on spojrzeć inaczej na nowoczesną teorię symbolu religijnego: samo jej pojawienie się stanowi interesujący fenomen nowoczesnego dyskursu religijnego, niemniej jej użyteczność jako narzędzia naukowego opisu języka religii jest bardzo ograniczona. Obrona języka religijnego przez wskazanie na szczególne prawa trybu symbolicznego jest - by nawiązać do motta tego tekstu zaczerpniętego od Umberta Eco - zawarciem traktatu z sekularnym bóstwem. Poświęcając autonomię języka religii gwarantowaną właściwym mu systemem różnic, zyskuje się możliwość jego przetrwania w formie religijnego symbolizmu. Postromantyczny „symbol” jest nośnym i potrzebnym pojęciem nowoczesnego dyskursu religijnego dokładnie z tego samego powodu, z którego nie przystaje on do oryginalnego doświadczenia religijnego: stanowi próbę przystosowania systemu religijnego do obserwacji z sekularnego zewnętrza. 
Bibliografia:

/// Assmann J. 2008. Pamieć kulturowa. Pismo, rapamietywanie i polityczna tożsamośc w cywilizacjach starożytnych, tłum. A. Kryczyńska-Pham, Wydawnictwa Uniwersytetu Warszawskiego, Warszawa.

/// Augustyn. 1961. De Magistro liber unus, Hoelder-Pichler-Tempsky, Wien.

/// Augustyn. 1969. Sermo de disciplina christiana, [w:] tegoż, Sancti Aurelii Augustini De fide rerum invisibilium; Enchiridion ad Laurentium de fide et spe et caritate; De catechizandis rudibus; Sermo ad catechumenos de symbolo; Sermo de disciplina christiana; Sermo de utilitate ieinnii; Sermo de excidio urbis Romae; De haeresibus, Brepols, Turnholtum, s. 203-224.

/// Augustyn. 1989. De doctrina christiana, O nauce chrześsijañskiej, tłum. J. Sulowski, Instytut Wydawniczy PAX, Warszawa.

/// Augustyn. 1999. O nauczycielu, tłum. J. Modrzejewski, [w:] tegoż, Dialogi filozoficzne, tłum. RA. Świderków i inni, Wydawnictwo Znak, Kraków, s. 421-485.

/// Blumenberg H. 2009. Praca nad mitem, tłum. K. Najdek, M. Herer, Z. Zwoliński, Oficyna Naukowa, Warszawa.

/// Congar Y.M.J. 1960. „Traditio” und „Sacra doctrina” bei Thomas von Aquin, [w:] Kirche und Überlieferung, red. J. Betz und H. Fries, Herder, Freiburg, Basel, Wien, s. 170-210.

/// Eco U. 1999. Tryb symboliczny, [w:] tegoż, Czytanie świata, tłum. M. Woźniak, Wydawnictwo Znak, Kraków, s. 137-205.

/// Eco U. 2006. Sztuka i piekno w średniowieczu, tłum. M. Kimula, M. Olszewski, Wydawnictwo Znak, Kraków.

/// Eliade M. 1998. Obrazy i symbole, tłum. M. i P. Rodakowie, Wydawnictwo KR, Warszawa.

/// Gadamer H.-G. 2007. Prawda i metoda, tłum. B. Baran, Wydawnictwo Naukowe PWN, Warszawa.

/// Habermas J. 2007. Filozoficzny dyskurs nowoczesności, tłum. M. Lukasiewicz, Universitas, Kraków. 
/// Hegel G.W.F. 1999. Najstarszy program systemu niemieckiego idealizmu, [w:] tegoż, Pisma wcresne z filozofii religii, tłum. G. Sowiński, Wydawnictwo Znak, Kraków, s. 275-277.

/// Heidegger M. 2007. Bycie i czas, tłum. B. Baran, Wydawnictwo Naukowe PWN, Warszawa.

/// Jung C.G. 1954. Über dei Archetypen des kollekitven Unbewussten, [w:] tegoż, Von den wurzeln des Bewusstseins; Studein über den Archetypus, Rascher-Verlag, Zürich, s. 3-36.

/// Jackson B.D. 1969. The Theory of Signs in St. Augustines De Doctrina Christiana, „Revue des études augustiniennes”, nr 15, s. 9-49.

/// Kant I. 2004. Krytyka władzy sadzenia, tłum. J. Gałecki, Wydawnictwo Naukowe PWN, Warszawa.

/// Ladner G.B. 1979. Medieval and Modern Understanding of Symbolism. A Comparison, „Speculum. Journal of Medieval Studies”, vol. 54, nr 2, s. 223-256.

/// Löwith K. 2001. Od Hegla do Nietzsschego. Rewolucyjny przetom w mysli XIX wieku, tłum. S. Gromadzki, Wydawnictwo KR, Warszawa.

/// Lubac de H. 1997. Stowo Boga w historii czlowieka, tłum. B. Czarnomorska, Wydawnictwo M, Wydawnictwo Znak, Kraków.

/// Lubac de H. 2000. Medieval Exegesis. The Four Senses of Scripture, t. 2, thum. E.M. Macierowski, Wm. B. Eerdmans Publishing Co., Michigan.

/// Luhmann N. 1998. Funkcja religii, tłum. D. Motak, Nomos, Kraków.

/// Lurker M. 1994. Prrestanie symboli w mitach, kulturach i religiach, tłum. R. Wojnakowski, Wydawnictwo Znak, Kraków.

/// McInerny R. 1996. Aquinas and analogy, Catholic Univeristy of America Press, Washington.

/// Morris C.W. 1944. Foundations of Theory of Signs, The University of Chicago Press, Chicago.

/// Piotr Lombard 1971. Sententiae in IV Libris Distinctae, t. I, Editiones Collegii S. Bonaventurae Ad Claras Aquas, Grottaferrata.

/// Press G.A. 1984. 'Doctrina' in Augustine's De doctrina christiana, „Philosophy and Rhetoric", nr 2, s. 98-120. 
/// Ratzinger J. 2011. O pojeciu sakramentu, [w:] tegoż, Sacrament i misterium. Teologia liturgii, tłum. A. Głos, Fundacja Dominikański Ośrodek Liturgiczny, Wydawnictwo AA, Kraków.

/// Ricœur P. 1985a. „Symbol daje do myślenia”, tłum. S. Cichowicz, [w:] tegoż, Egzystencja $i$ bermenentyka. Rozprawy o metodzie, tłum. E. Bieńkowska i inni, Instytut Wydawniczy PAX, Warszawa, s. 58-75.

/// Ricœur P. 1985b. Hermenentyka symboli a refleksja filozoficzna - I, tłum. H. Bortnowska, [w:] tegoż, Egzystencja i hermenentyka. Rozprawy o metodzie, tłum. E. Bieńkowska i inni, Instytut Wydawniczy PAX, Warszawa, s. 76104.

/// Ricœur P. 1985c. Hermenentyka symboli a refleksja filozoficzna - II, tłum. J. Skoczylas, [w:] tegoż, Egzystencja i hermenentyka. Rozprawy o metodzie, tłum. E. Bieńkowska i inni, Instytut Wydawniczy PAX, Warszawa, s.105-123.

/// Ricœur P. 2008. O interpretacji. Esej o Frendzie, tłum. R. Reszke, Wydawnictwo KR, Warszawa.

/// Rorty R. 2009. Pryygodność, ironia, solidarność, tłum. W.J. Popowski, Wydawnictwo W.A.B., Warszawa.

/// Schelling F.W. 1983. Filozofia sžtuki, tłum. K. Krzemieniowa, Państwowy Instytut Wydawniczy, Warszawa.

/// Simone R. 1973. Semiotyka augustyńska, [w:] Studia z bistorii semiotyki, red. J. Sulowski, t. 2, Zakład Narodowy im. Ossolińskich, Wrocław, s. 15-42.

/// Spaemann R., Löw R. 2008. Cele naturalne. Drieje i ponowne odkrycie myślenia teleologicznego, tłum. A. Półtawski, Oficyna Naukowa, Warszawa.

/// Sulowski J. 1989. Przedmowa, [w:] Augustyn, De doctrina christiana, O nauce chræeśsijańskiej, Instytut Wydawniczy PAX, Warszawa, s. V-XXXI.

/// Tillich P. 1966. Symbol und Wirklichkeit, Vandenhoeck and Ruprecht Verlag, Göttingen.

/// Tillich P. 1994. Symboliẓm religijny, [w:] tegoż, Pytanie o Nieuwarunkowane. Pisma z filozofii religii, tłum. J. Zychowicz, Wydawnictwo Znak, Kraków, s. $135-211$.

/// Todorov T. 2011. Teorie symbolu, tłum. T. Stróżyński, Słowo/Obraz Terytoria, Gdańsk. 
/// Tomasz z Akwinu. 1929. Scriptum super Libros Sententiarum, tom I, Lethielleux, Paris.

/// Tomasz z Akwinu. 1948. Summa Theologiae, Marietti, Romae.

/// Torrell J.-P. 2005. Koncepcja wied₹y teologicznej wedtug św. Tomasza i pierwszych tomistón, tłum. A. Kuryś, [w:] Świety Tomasz teolog. Wybór studiów, red. M. Paluch, tłum. Z. Bomert, A. Kuryś, P. Lichacz, Instytut Tomistyczny, Wydawnictwo Antyk, Warszawa, Kęty, s. 57-135.

\section{/// Abstrakt}

Tekst zawiera krytykę postromantycznej teorii symbolu religijnego. Jego główna teza głosi, że pojęcie symbolu religijnego jest pojęciem kompensacyjnym, które pozwala zaabsorbować koszty procesu sekularyzacji. Teza ta uzasadniona zostaje przez podanie szkicu oryginalnej semiotyki języka religijnego na podstawie pism św. Augustyna, zgodnie z którą język religijny charakteryzuje się (1) semantycznym zdefiniowaniem, (2) syntaktyczną koherencją i (3) pragmatycznym sprzężeniem z dyscypliną. Cechy te odróżniaja go od systemu romantycznych symboli charakteryzujących się niedodefiniowanym znaczeniem oraz luźnymi związkami z innymi symbolami i obliczonych na wolne od przymusu przyswojenie. Postromantyczny „symbol” jest więc nośnym pojęciem nowoczesnego dyskursu religijnego dokładnie $\mathrm{z}$ tego samego powodu, $\mathrm{z}$ którego nie przystaje on do oryginalnego doświadczenia religijnego: zakłada on redefinicję konstytutywnych cech oryginalnej struktury języka religii.

Słowa kluczowe:

teoria symbolu, sekularyzacja, hermeneutyka, Św. Augustyn

\section{/// Abstract}

The paper contains a critique of the postromantic theory of religious symbol. A main claim of the paper is that the notion of „religious symbol” is a compensatory nation, which serves to absorb the costs of the secularization process. This claim is supported by an outline of the original semiotics of religious language from works of St. Augustine. In accordance with this semiotics the religious language is (1) semantically defined, (2) syntactically coherent and (3) used in the pragmatic context of religious discipline. This features distinguish the religious language from the system 
of romantic symbols, which have the undefined meaning, constitute the loose structure and are used in the coercion-free pragmatic context. There is one reason both for the fact that postromantic „symbol" is an important notion of the modern religious discourse and the fact that „symbol” unfits to describe the original religious experience: ,symbol" bases on the redefinition of original structure of religious language.

Keywords:

symbol theory, secularization, hermeneutics, St. Augustine 